\title{
DESIGN AND BUILD OF AUTOMATIC WASTAFEL USING ULTRASOUND HC-SR04 SENSOR BASED ON ARDUINO
}

\author{
Henry Prasetyo*1, Mohammad Rofi' ${ }^{2}$, Septiana Kurniasari ${ }^{3}$, Muhammad Wisnu \\ Pamungkas ${ }^{1}$ \\ ${ }^{1}$ Electromedic Engineering, Bina Trada Polytechnic \\ Jl. Sambiroto Raya No.64, Semarang 50276 \\ ${ }^{2}$ Electromedic Engineering, Electromedical Engineering Academy Semarang \\ Jl. Kolonel Warsito Sugiarto 172 Km, Semarang 50222 \\ ${ }^{3}$ Department of Physics, Mathematic and Natural Science of Faculty, Gorontalo State University \\ Jl. Jend. Sudirman No.6, Gorontalo
}

\begin{abstract}
The lack of public concern for washing hands during the Covid-19 pandemic, the authors designed an automatic sink using an arduino-based HC-SR04 ultrasound sensor to attract the public's interest. By making automatic sink technology using the HC-SR04 ultrasound sensor based on Arduino for use in hand washing by the community. This study uses experimental research that examines the effect of automatic washbasin with people's behavior in washing hands. By testing the use of water in 20 seconds, 43 people can use it in one day, and soap can be used by 6 people in one day in 5 seconds. The automatic sink using the HC-SR04 ultrasound sensor based arduino can be used with a distance that is made less than $15 \mathrm{~cm}$ designed to be practical and sterile because it is used that does not touch faucets or soap. The conclusion of the study is that if there is an object that approaches the ultrasound sensor within a distance of less than $15 \mathrm{~cm}$, the water pump will be active for 20 seconds or the soap pump for 5 seconds will automatically come out. And it will run out if used for 934 seconds in 1 liter gallon or 46 people a day and the use of soap for 5 seconds will run out approximately 6 people in one day.
\end{abstract}

Keywords: Ultrasonic sensor; Automatic wastafel; Arduino

\section{Introduction}

In February 2019 the corona virus or (covid-19) apparently created panic in the community. The corona virus has spread in 75 major countries in the world, and has even killed more than 3000 people. As a result of this, many people have started to seek protection to prevent transmission of the corona virus. As many have discussed, the way to prevent the corona virus is to diligently wash your hands. The World Health Organization (WHO) said washing hands is an effective first step to prevent all diseases, such as gastrointestinal infections and respiratory diseases. ${ }^{1}$

According to the World Health Organization (WHO) washing hands is a way to prevent the Covid-19 virus. Washing hands

\footnotetext{
*Corresponding author.

E-Mail: henryprasetyo1212@gmail.com
}

is an effective first step to prevent all diseases, such as gastrointestinal infections and respiratory diseases. ${ }^{2}$

Therefore, researchers designed a device called an automatic sink designed using an arduino-based HC-SR04 ultrasound sensor using a mini pump for water and soap using the HC-SR04 ultrasound sensor as object detector, Arduino as a control system and relay as a circuit breaker on the pump. which aims to turn off or turn on the pump and is equipped with a sink as a place for washing hands. With this tool, users no longer need to touch a tap or soap.

The main component used for this tool is a microcontroller. A microcontroller is a computer system where all or part of its elements are packaged in an IC chip. ${ }^{3}$ So this microcontroller is a tool that will be used to 
transfer programming from a computer into a device. This microcontroller has various types with different features for each type. Meanwhile, the microcontroller used for this automatic sink is the Arduino Uno microcontroller, because this microcontroller has features that are suitable for tools that use push button switches, Relay modules, infrared sensors, soap and water pumps, and LCD screens. there is a small automatic wastafel. ${ }^{4}$

Apart from the microcontroller, the ultrasound sensor is also very vital in this tool. In ultrasonic sensors, ultrasonic waves are generated through a device called a pieozoelectric with a certain frequency. This pieozoelectric will produce ultrasonic waves (generally $40 \mathrm{~Hz}$ ) when an oscillator is applied to the object. In general, this tool will shoot ultrasonic waves towards an area or a target. After the wave hits the target surface, the target will reflect the wave back. The reflected wave will be received by the sensor, then the sensor calculates the difference between the time the wave is transmitted and the time it is received. ${ }^{5}$
Previous research related to design automatic wastafel based on microcontroller with photodiode sensor with distance of $5 \mathrm{~cm}$ from the hand dryer. ${ }^{6}$ In addition, there is also research entitled the design of a slar-powered automatic portable wastafek as a protection against Covid-19. This research uses solar power as a driving force. ${ }^{7}$

\section{Methods}

\section{System Design Stage}

The system design is done by designing the entire system from all the components used and the workflow of the automatic sink. The design of the tool is that the ultrasound sensor is placed on the outside of the tool part close to the water and soap hose so that the tool works properly. On the inside of the tool there is an Arduino Uno, and a Relay. The sensor is placed close to the soap so that the pump can move the liquid line. The design of the automatic sink can be seen in Figure 1.

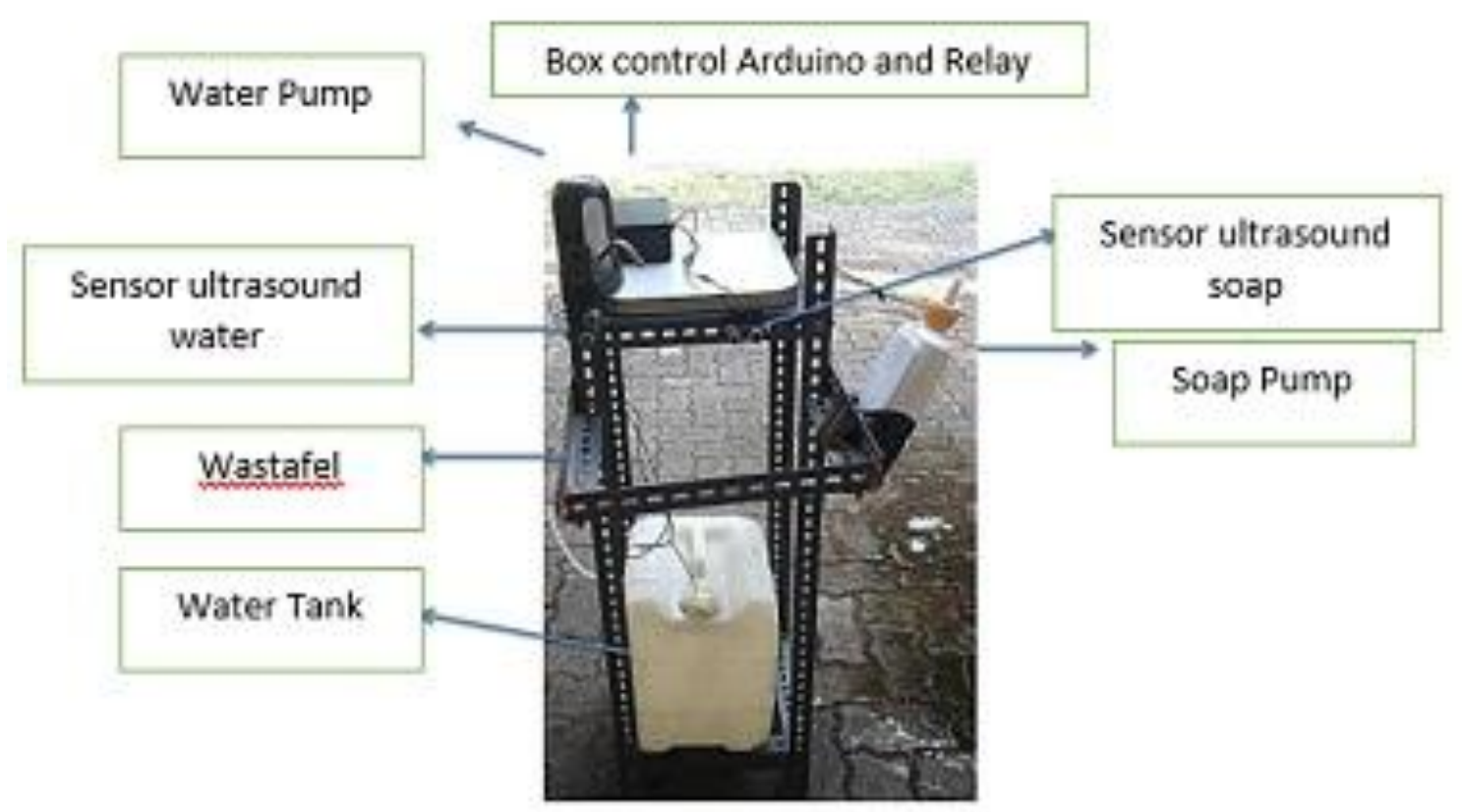

Figure 1. Automatic Wastafel's Design

\section{Circuit Design Stage}

The circuit design is done by designing a series of automatic sink devices such as a series of sensors, mini pumps and Arduino uno which have been arranged in several blocks. The circuit is made on the project board to prevent damage to components and waste of components due to short circuits. The whole series is shown in Figure 2. 


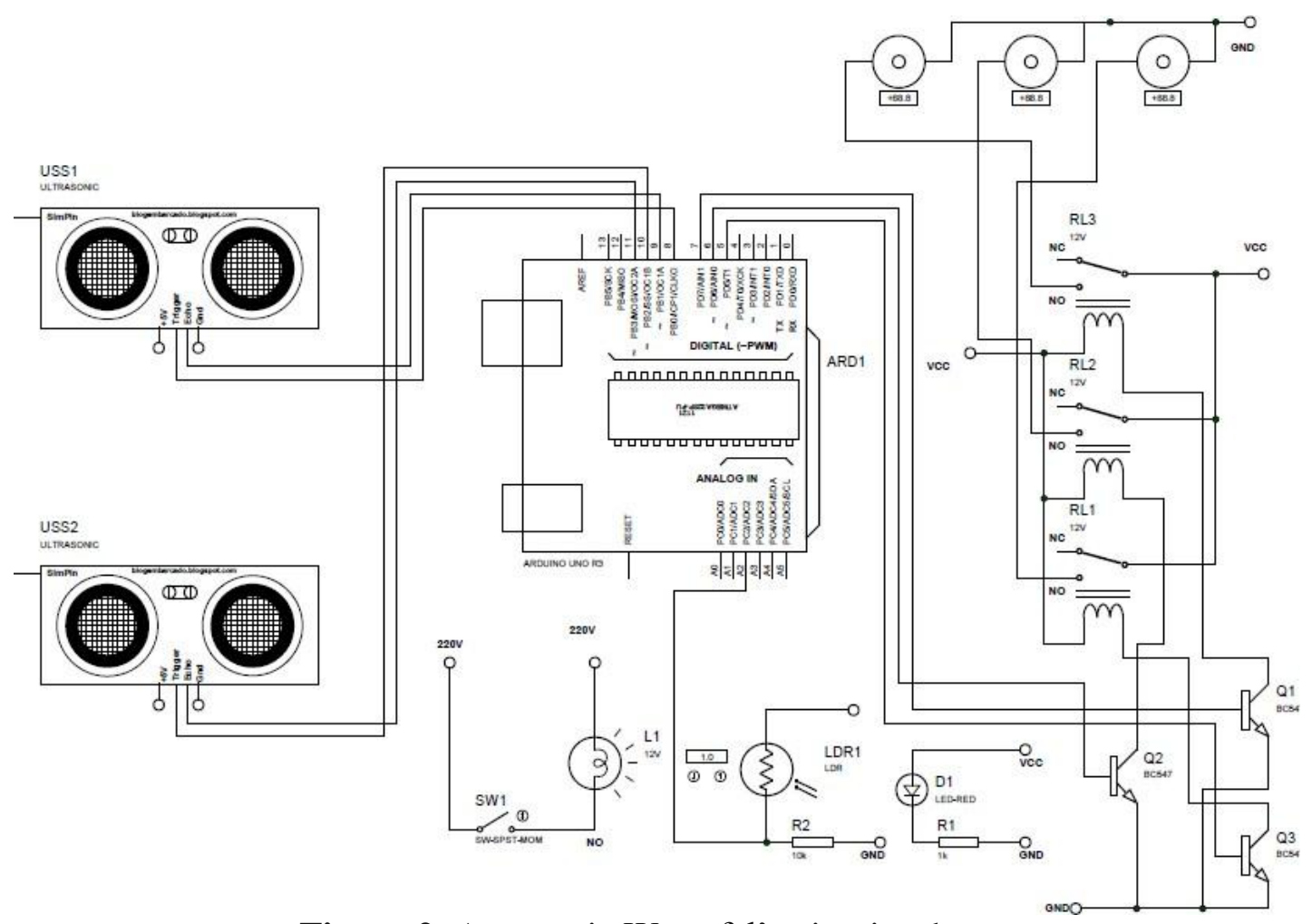

Figure 2. Automatic Wastafel's circuit scheme
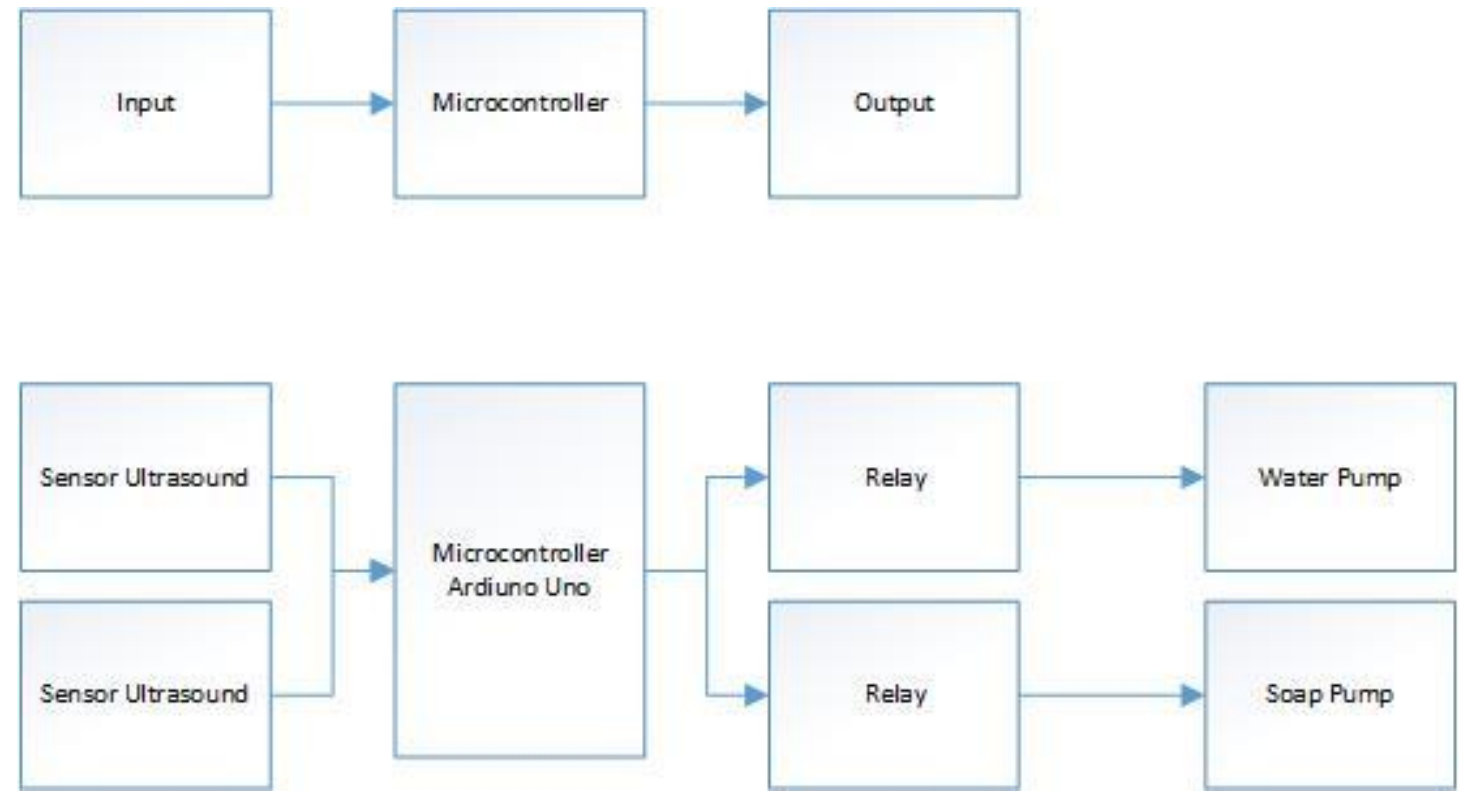

Figure 3. Flowchart block diagram system

In Figure 3 is a design block diagram that provides information between components based on the direction of the arrow, Arduino has the role of regulating the components for standby so that they can respond to each component connected to the sensor to be able to work like the components in a mini pump, a pump that is responsible for moving lanes. water from the water and soap baths are in charge of moving the soap liquid lines so that they can come out. ${ }^{5}$

\section{Tool Making Stage}

The making of tools is designed by doing schematic and circuit simulation on the software and project board that has been designed. 


\section{Tool Testing Stage}

Tool testing is carried out after the circuit has been successfully designed and carried out by testing the overall framework of the system. This test is carried out to prevent system failure of each component of the tool. Then the test is carried out by examining each system flow that has been designed in Figure 4.

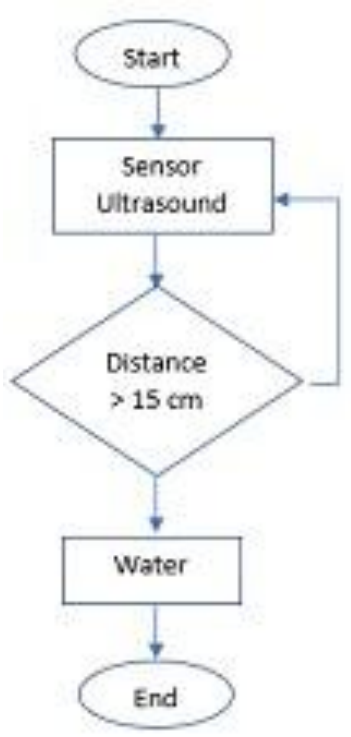

Figure 4. a. Water sensor flow chart

The testing phase is carried out by testing two sensors, namely the sensor that is on the electric pump to move the water and the sensor on the motor that drives the soap.

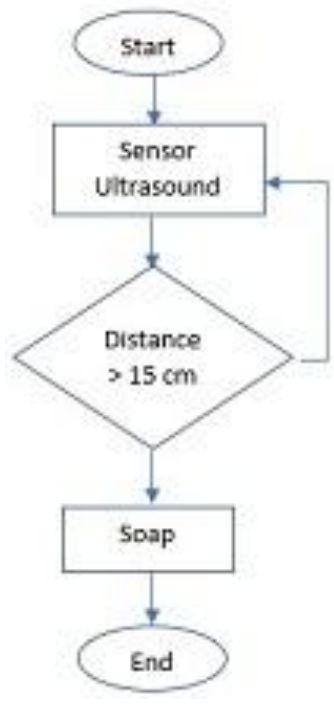

Figure 4. b. Soap sensor flow chart

\section{Tool Analysis Stage}

When the testing of the tool has been completed, an analysis of the automatic sink tool is carried out. The analysis includes the work system of the two sensors, the work system for electric pumps, and the work system for the soap driving servo, as well as the more practical and economical advantages of the automatic wastafel.

\section{Arduino IDE Design Software}

In using Arduino, of course, really needs support from Arduino software. The Arduino software that will be used is the driver and IDE.

One of them that wants to be developed is an automatic sink, which really needs to arrange components with the Arduino program. By writing some of the required code, the tool will work according to the program that we created.

Regarding ultrasound sensor programming, it can be seen in Figure 5. In Figure 5 is the main program on an automatic sink, which is to run commands on the water sensor at points ( 1 to 5 ) for distance and duration at points (6 to 7). for points ( 8 to 14 ) is a soap sensor program that is made the same as point (1) except that it distinguishes the last name in writing.

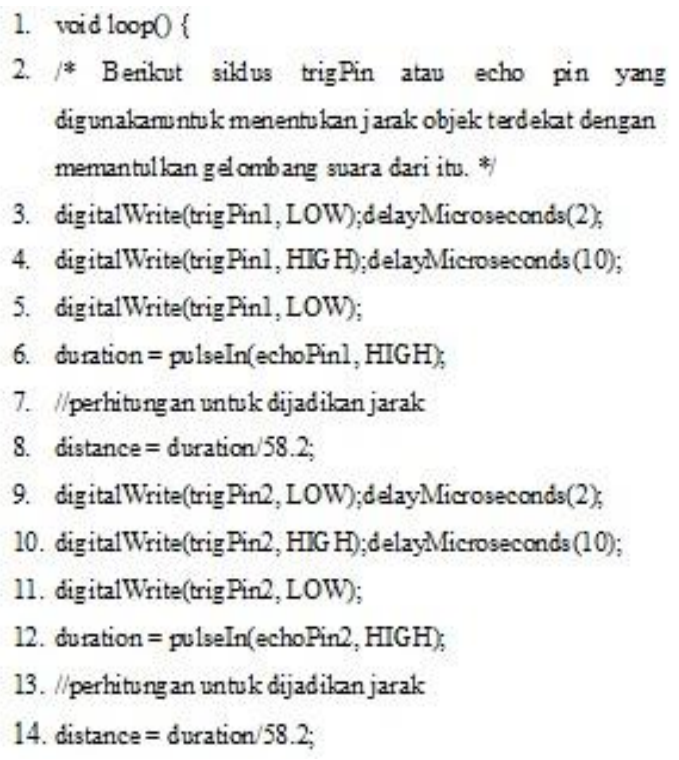

Figure 5. Arduino IDE programming for ultrasound sensors 
For water sensors, the programming script can be seen in Figure 6. In Figure 8 is to set the distance used and sent to the serial monitor at points (1, to 21$)$ at points (5 to 21$)$ is a program when the ultrasound sensor gets a distance which has been set to determine a distance value, then the Relay will be active according to the specified distance and the delay made is 20 seconds.

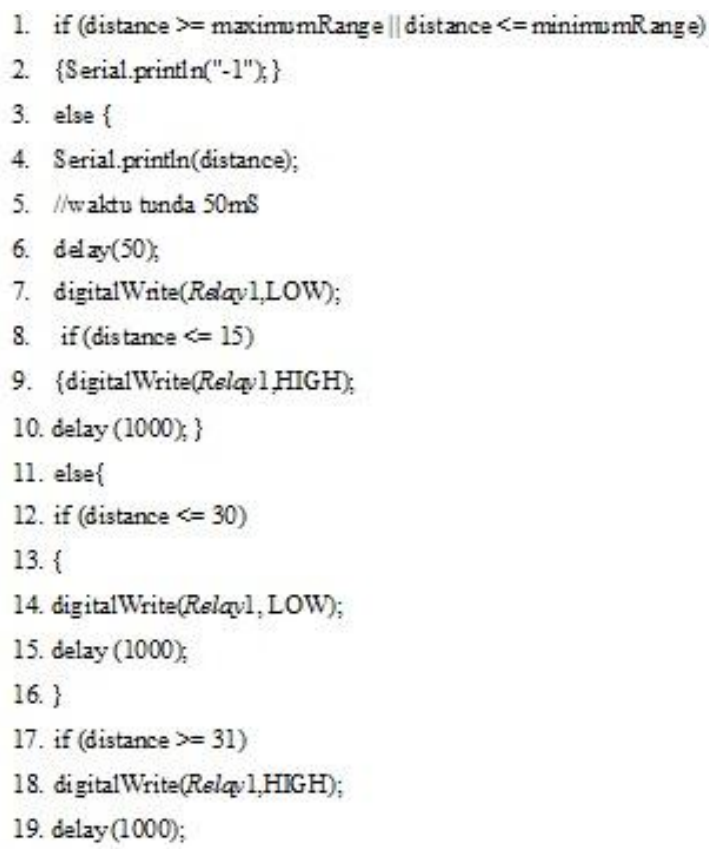

Figure 6. Water Sensor Programming

For soap sensor programming, it can be seen in Figure 8. This program is used for soap sensors at points (1 to 20) and the delay used is 1 second.

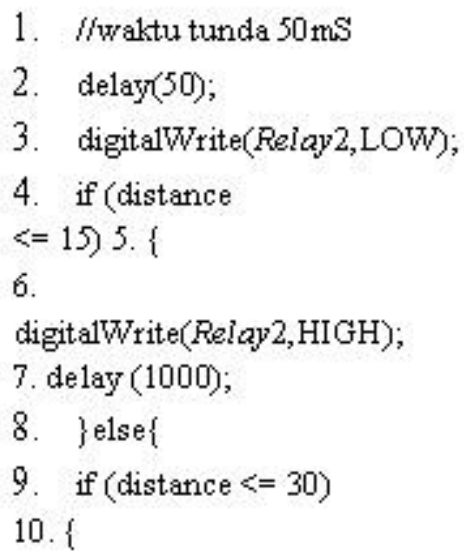

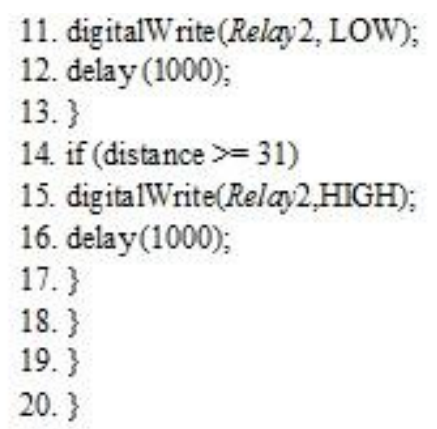

Figure 7. Soap Sensor Programming

\section{Result and Discussion}

\section{Testing Mini Pumps On Water}

The water tap installed on the sink is made for the passage of water discharged by the pump. The 6 volt dc pump is classified as an electromagnetic device that converts electrical energy into mechanical energy.

Testing is done by adjusting the seconds on the water sensor in determining the water that comes out in one use. The results of the mini water pump test can be seen in Table 1 .

Table 1. Mini Water Pump Test Results

\begin{tabular}{ll}
\hline Test Phase & Time (20 second) \\
\hline Test 1 & $406,3 \mathrm{~mL}$ \\
Test 2 & $407,5 \mathrm{~mL}$ \\
Test 3 & $407,0 \mathrm{~mL}$ \\
Average & $407 \mathrm{~mL}$ \\
\hline
\end{tabular}

Calculations for 19 liters of water or 1 gallon of water can be seen in Table 2 .

Table 2. Calculation of Water in 1 Gallon

\begin{tabular}{cc}
\hline Time (second) & $\begin{array}{c}\text { Average Test 1, 2, 3 } \\
(\mathbf{~ m L})\end{array}$ \\
\hline 20 second & $407 \mathrm{~mL}$ \\
3600 second (1 hour) & $73.260 \mathrm{~mL}$ \\
\hline
\end{tabular}

For the calculation of gallon water (19 liters) as follows:

19 liters $=19000 \mathrm{ml}$

19 liters $=918$ seconds

The calculation is obtained from:

$$
\frac{3600 \text { second }}{73.260 \mathrm{~mL}}=\frac{x \text { second }}{19.000 \mathrm{~mL}}
$$




$$
\begin{gathered}
x \text { second }=\frac{19.000 \times 3600}{73.260} \\
x \text { second }=933,6 \\
x=934 \text { detik }
\end{gathered}
$$

So it is obtained that every 19 liters of water is used in 934 seconds, the conclusion is that in one gallon it can be used as much as 934 seconds or approximately 46 people in one day.

\section{Testing Mini Pumps on Soap}

The soap tube used in it has a 6volt DC pump inserted to move the soap liquid line by relying on electrical energy that has been converted into mechanical energy from the mini pump.

Testing is done by adjusting the seconds on the soap sensor to determine which soap comes out in one use. The soap pump test results can be seen in Table 3 .

Table 3. Mini Soap Pump Test Results

\begin{tabular}{ll}
\hline Test Phase & Waktu ( 5 detik) \\
\hline Test 1 & $97,5 \mathrm{~mL}$ \\
Test 2 & $95,4 \mathrm{~mL}$ \\
Test 3 & $96,0 \mathrm{~mL}$ \\
Average & $97 \mathrm{~mL}$ \\
\hline
\end{tabular}

The soap holder used can hold as much as 600 $\mathrm{ml}$ of soap, thus the measurements are obtained in Table 5.The Soap Test Results are as follows:

Table 5.Test Results of Mini Soap Pumps

\begin{tabular}{cc}
\hline Time (second) & $\begin{array}{c}\text { Average Test 1,2,3 } \\
(\mathbf{m L})\end{array}$ \\
\hline 5 second & $97 \mathrm{~mL}$ \\
3600 second & $69.840 \mathrm{~mL}$ \\
(1 hour) & \\
\hline
\end{tabular}

1 bottle $=600 \mathrm{ml}$

1 second $=97 \mathrm{ml}$

$$
\frac{1 \text { second }}{97 m L}=\frac{x \text { second }}{600 m L}
$$

$$
\begin{aligned}
x \text { second } & =\frac{1 \text { second } x 600 \mathrm{~mL}}{97 \mathrm{~mL}} \\
\mathrm{x} & =6,18 \text { second }
\end{aligned}
$$

So every 1 bottle of soap can be used by approximately 6 people in one day.

\section{Conclusion}

1. Automatic Washbasin has a working system where if there is an object approaching the ultrasound sensor within a distance of less than $15 \mathrm{~cm}$, the water pump will be active for 20 seconds or the soap pump for 5 seconds will automatically come out. This distance is made less than $15 \mathrm{~cm}$ to avoid if there are objects that accidentally pass through the sensor to activate the water and soap pump.

2. The results of the water test are carried out by weighing for 20 seconds and soap is carried out for 5 seconds separately from water, then the results that come out will be calculated by means of a comparison where the water comes out for 20 seconds will run out if used for 934 seconds in 1 liter gallon or 46 people a day and using soap for 5 seconds will be used up by approximately 6 people in one day.

\section{Acknowledgment}

Thanks to fellow lecturers and staff of the Bina Trada Polytechnic, so that this journal can be completed properly.

\section{References}

1. Prasetyo, Deni. Perancangan Prototipe Alat Cuci Tangan Otomatis dengan Sensor Ultrasonik Hc-Sr04 Berbasis Pengendali Mikro.Jurnal cyber-tech. 2015; 10(1): p. 18

2. Gunawan. Anomaly covid-19, dampak positif virus corona untuk dunia. Purwokerto: Publisher CV IRDH; 2020.

3. Wahyudin. Belajar Mudah Mikrokontroler AT89S52 dengan Bahasa BASIC Menggunakan BASCOM-8051. $2^{\text {nd }}$ edition.Yogyakarta: Publisher Andi; 2007. 
4. Santoso, Hari. Panduan Praktis Arduino Untuk Pemula. $2^{\text {nd }}$ edition. Yogyakarta: Publisher Andi; 2015.

5. Santoso, Hendry. Mesin Cuci Tangan Otomatis Menggunakan Sensor Optokopler. Yogyakarta: Publisher Universitas Sanata Dharma, 2008.

6. Riski, Hafizur. Rancang Bangun Sistem Wastafel Otomatis Mikrokontroler ATmega 8535 dengan Menggunakan Sensor Fotodioda. Jurnal Fisika Unand. 2015; 4(2): p.106-112.

7. Nugraha, Aditya. Rancang Bangun Wastafel Portabel Otomatis Bertenaga Surya Sebagai Proteksi Pencegahan Covid19. Jurnal Ilmiah Ilmu dan Teknologi Rekayasa Polsub. 2020; 3(2): p. 48-53. 